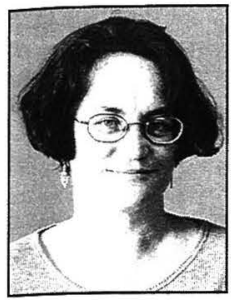

\title{
HOMECARE WORKERS: A CASE STUDY OF A FEMALE OCCUPATION
}

\author{
Máire Dwyer
}

Consultant

\begin{abstract}
The research was carried out for the Ministry of Women's Affairs by Máire Dwyer, Janice Burns, Jo Lynch and Huia ngarangi-Lambie. The aim was to investigate the factors that influenced the pay and conditions of homecare workers.

A literature review was carried out in tandem with a small programme of field research which involved interviews with funders, six home care agencies, workers and clients.

The study found that the factors that led to low pay and conditions for homecare workers in New Zealand were substantially similar to those identified in the literature. Wages were low, $\$ 8.50-\$ 10.50$ an hour, with effective wages even lower as no agencies paid for travel time and half did not pay allowances for using own vehicles. Only half the workers had received training, and most workers spent more time than paid for with some clients.
\end{abstract}

Keywords: gender earning gap, homecare workers, valuing care, employment contracts

This project, undertaken by Máire Dwyer, Janice Burns, Jo Lynch and Huia ngarangi-Lambie, forms part of the Ministry of Women's Affairs earnings gap programme of research which aims to better understand the causes of the earnings gap between women and men.

\section{The research brief was to:}

1. Investigate the factors which affect the wages and con ditions of homecare workers, and in particular:

- How homecare work is described and valued.

- Factors which result in, or reinforce, the undervaluing of homecare work.

- The impact of employment practices and contracting of homecare services on job security, wages, conditions of employment, training and health and safety.

2. Draw out any findings on how pay and conditions affect the quality of homecare.

3. Identify Maori perspectives on the homecare tasks and their value, and if and how Maori homecare workers fare differently from non-Maori homecare workers.

The research included homecare workers who were formally employed by an agency to undertake personal care and household management in a client's home. These services are most commonly accessed through Health Funding Authority's (HFA) disability support provisions. It does not include unpaid family members (who are estimated to un- dertake approximately $75 \%$ of all care), family members paid on a one-off basis to provide care, or those providing care on a voluntary or substantially voluntary basis, such as Meals on Wheels volunteers. It also excludes those who contract on their own account directly with clients.

\section{Methodology}

A variety of sources of information were accessed for the study. National and international literature on factors that affected wages and conditions, and the valuing of homecare work was reviewed. The primary research was designed to gather information from homecare workers, their employers and their clients. The research approach was to take a vertical slice into the homecare industry in order to explore the relationships between the two main government funders (the Health Funding Authority (HFA) and the Accident Rehabilitation \& Compensation Insurance Corporation (ACC)), the assessors who decide on the need for care services, the agencies contracted to provide services, and the workers employed by and clients of those agencies.

\section{Those involved in the study included:}

\section{Homecare service providers}

Six agencies were selected from a list of those contracted or subcontracted for homecare services by HFA, North Office (2) and HFA, Central Office (4), two of the four regional operations of the HFA. The researchers made a purposeful selection to include larger national agencies, small agencies, and regional and Maori agencies. Of the 
six service providers, two employed approximately 700 workers, one employed 400 workers, another employed 150 , and the two Maori agencies both employed fewer than 35 workers.

\section{Homecare Workers}

28 homecare workers were interviewed. The selection process involved a randorn selection of up to 100 workers from each provider (depending on the size of the agency) who were then given the opportunity by their employer to opt out of the research. The list of workers was then supplied to the researchers who randomly selected five workers per agency. The researchers then contacted those selected by phone to invite them to take part in the study. An interview time was arranged and the worker was sent information about the study and a consent form. In one very small Maori agency it was only possible to interview three workers. Ten of the 28 workers interviewed were Maori.

\section{Clients}

Up to 20 clients were randomly selected by each provider and invited to participate directly in the research by returning a signed form to the researchers. It had been intended to interview 18 clients (three from each provider) but the final number was 15 , of whom 12 were receiving household management service and three were receiving personal care. It appeared that clients receiving personal care were less inclined to be part of the study.

\section{Other key informants}

The field research was supported by interviews with key informants within the homecare industry who included:

- Ministry of Health staff responsible for the homecare policy and standards.

- ACC staff responsible for homecare policy and standards.

- Managers from three funding agencies: two HFA regional divisions (North Office and Central Office, who were selected to take account of different funding regimes and geographic location), and the Otahuhu Branch of the ACC (selected because it was within the HFA, North Office region).

- Assessors from three agencies responsible for assessing client need: Facilitated Access to Coordinated Services (FACS) in the HFA, Central Office area; a hospital-based service in HFA, North Office providing assessment of clients over 65 years old; and an independent contractor to ACC.

- Service Workers Union and Nurses Association representatives.

- Representatives from the Home Support Association and a small selection of hospital-based homecare, rest home, and private hospital service providers.

While the field research design aimed to provide reasonable coverage of the different funding and contractual ar- rangements for homecare work, and to maximise findings for Maori, it involved only a very small number of providers, care workers and clients. The results therefore cannot be generalised to homecare arrangements throughout New Zealand.

The size of the study also means that the results cannot be used to make a meaningful comparison of the remuneration practices of non-profit and for-profit agencies, nor of Maori and non-Maori agencies. Due to the size of the study no attempt was made to identify any differences for Pacific Island or other ethnic groups.

\section{The effective hourly pay rates of homecare workers in the study}

When travel costs (including unpaid time) are taken into account, the actual remuneration of agency workers for time spent in client contact or travelling between clients is considerably less than the hourly rate paid for 'eligible' hours. Using the Inland Revenue allowable travel expense of $62 \mathrm{c}$ / $\mathrm{km}$ for self-employed people as a benchmark for full travel cost compensation, and cases developed from the study, some examples of effective gross hourly pay rates are:

Worker A: 7 clients, 15 hours client work over 4 days; hourly pay rate $\$ 10.00$; 40 kilometres travelled between clients ( 1.5 hours/week); no travel allowance. Her effective hourly rate is $\$ 7.59$. With an extra 0.5 hours/week of unpaid activities, that rate falls to $\$ 7.36$.

Worker B: 12 clients, 28 hours client work over 5 days; hourly pay rate $\$ 9.38$; 100 kilometres travelled between clients ( 3.0 hours/week); travel allowance of $40 \mathrm{c} / \mathrm{km}$. Her effective hourly rate is $\$ 7.76$. With an extra 0.5 hours/ week of unpaid activities, that rate falls to $\$ 7.63$

Worker C: 2 clients, 4 hours client work over 2 days; hourly pay rate $\$ 9.00 ; 15$ kilometres travelled between clients ( 0.5 hours/week); no travel allowance. Her effective hourly rate is $\$ 5.93$. With an extra 0.5 hours/week of unpaid activities, that rate falls to $\$ 5.34$.

Worker D: 10 clients, 20 hours client work over 5 days; hourly pay rate $\$ 8.90$; 80 kilometres travelled between clients ( 2.5 hours/week); travel allowance of $30 \mathrm{c} / \mathrm{km}$ for travel over $10 \mathrm{~km} /$ day. Her effective hourly rate is $\$ 6.11$. With an extra 0.5 hours/week of unpaid activities, that rate falls to $\$ 5.97$.

\section{Why poor wages and conditions?}

The literature identifies a number of general and genderrelated theories which explain why wages and conditions are lower than one might otherwise expect. The main theories are summarised briefly in the text that follows. 


\begin{tabular}{|c|c|}
\hline Issue & Research findings \\
\hline $\begin{array}{l}\text { Standard } \\
\text { provisions }\end{array}$ & $\begin{array}{l}\text { - All contracts contained the minimum leave provisions mandated in the } \\
\text { Employment Contracts Act and the Holidays Act. That is, entitlement to } 3 \text { weeks } \\
\text { holiday pay after } 12 \text { months, days-in-lieu for working statutory holidays, and } 5 \\
\text { days special leave after } 6 \text { months, on a pro-rata basis } \\
\text { - One agency had no formal contract }\end{array}$ \\
\hline Hours of work & $\begin{array}{l}\text { - No agency offered secure hours all workers had varied hours } \\
\text { - Range in research group was } 235+\text { hours per week. Workers providing services to } \\
\text { clients with high need are particularly vulnerable to fluctuating hours when clients } \\
\text { go into hospital. }\end{array}$ \\
\hline Hourly pay & $\begin{array}{l}\text { - } \$ 8.40 \$ 10.77 \text { for household management } \\
\text { - } \$ 9.00 \$ 10.77 \text { for personal care. Few workers earned more than } \$ 10.50 \text {. Some } \\
\text { wages higher due to historical factors. One agency had a scale to reflect } \\
\text { experience and performance } \\
\text { - Lower rates for overnight stays }\end{array}$ \\
\hline $\begin{array}{l}\text { Skills/other } \\
\text { requirements } \\
\text { for job }\end{array}$ & $\begin{array}{l}\text { - Agencies required, or could require, a police check } \\
\text { - Previous experience required for personal care work } \\
\text { - Communication skills } \\
\text { - Caring, reliable, compassionate } \\
\text { - Car in working order and phone (required by most agencies) }\end{array}$ \\
\hline $\begin{array}{l}\text { Transport } \\
\text { costs }\end{array}$ & $\begin{array}{l}\text { - Three agencies paid nothing } \\
\text { - Others varied from } 30 \mathrm{c} / \mathrm{km} \text { for mileage over } 10 \mathrm{~km} \text { a day between clients to } \\
40 \mathrm{c} / \mathrm{km} \text { for all mileage between clients }\end{array}$ \\
\hline $\begin{array}{l}\text { Costs/risks of } \\
\text { taking client } \\
\text { shopping }\end{array}$ & $\begin{array}{l}\text { - Two agencies had formal agreements that clients paid mileage for shopping } \\
\text { - Workers could ask clients for money in other agencies } \\
\text { - No agency ensures workers are covered by insurance while transporting clients }\end{array}$ \\
\hline $\begin{array}{l}\text { Equipment } \\
\text { costs }\end{array}$ & $\begin{array}{l}\text { - Most agencies provided equipment, although some workers provided their own } \\
\text { gloves } \\
\text { - Additional washing of own clothes as a result of work was done by worker }\end{array}$ \\
\hline Training & $\begin{array}{l}\text { - Five agencies provided training three provided in-house training free of charge } \\
\text { - One agency paid for two hours training/meetings per month } \\
\text { - One agency paid for two initial hours, and required a further } 6 \text { sessions per year } \\
\text { - Three agencies provided all training on an unpaid basis } \\
\text { - No agencies linked to NZ Qualifications Authority framework as yet }\end{array}$ \\
\hline $\begin{array}{l}\text { Unpaid work } \\
\text { (non-optional) }\end{array}$ & $\begin{array}{l}\text { - Travel time between clients (all agencies) } \\
\text { - Negotiating arrangements for new or existing clients with coordinators } \\
\text { - Discussing time sheets and performance appraisals } \\
\text { - Assisting with organising relief care (some agencies) } \\
\text { - Extra time to complete tasks on care plan }\end{array}$ \\
\hline $\begin{array}{l}\text { Other unpaid } \\
\text { work }\end{array}$ & - Many workers reported doing extra tasks for clients, and/or staying longer to chat \\
\hline $\begin{array}{l}\text { Freedom to } \\
\text { take on other } \\
\text { employment }\end{array}$ & $\begin{array}{l}\text { - One agency had a restraint of trade clause in contract } \\
\text { - Two agencies required workers to seek permission to take on other work } \\
\text { - One agency discouraged other work } \\
\text { - One agency accepted, and another encouraged, other work }\end{array}$ \\
\hline Redundancy & $\begin{array}{l}\text { - Two agencies had redundancy provisions in contract in lieu of notice ( } 2 \text { weeks } \\
\text { and } 4 \text { weeks) }\end{array}$ \\
\hline
\end{tabular}




\section{General theories:}

\section{Labour market segmentation}

The main argument here is that certain industries and jobs tend to be "bad payers" due to their particular market situation. Workers whose hours are constrained, do not have formal skills, or who face discrimination, end up in these jobs.

\section{Role of Government as funder}

Several overseas studies have demonstrated the impact of government's role of containing costs in the homecare industry on wages and conditions (Burbridge,1993; MacAdam, 1993).

\section{Contracting and competition}

The move from direct employment of workers to competitive contracting in the service sector tends to have a negative impact on jobs, remuneration and conditions, with women being more adversely affected than men. This is particularly the case where agencies have a limited bargaining position under competition.

\section{Gender:}

A number of related theories explore the role of gender in determining wages and conditions.

\section{Occupational segregation}

Where women and men do different work, work predominantly performed by women is generally regarded as being of lower value than work performed by men.

\section{Caring occupation.}

Three themes that emerge from the literature are:

- Gender-based expectations of care within families means women are conditioned to feel obliged to care for people who are vulnerable.

- Women do more than they are paid for in "caring' occupations for the same reasons that they do a disproportionate share of unpaid caring work within families.

- Nurturing and caring is an integral part of women's identity, and women undertake these roles, not simply because they have been assigned to them, but because they are meaningful and fulfilling.

\section{Valuing of the homecare job}

The literature indicated that undervaluing of the homecare job occurs as a result of:

- the emotional input and personalised needs assessment undertaken by homecare workers being discounted.

- Job descriptions focus on concrete tasks, so skills such as emotional support, communication skills, personal care skills, and companionship are rendered invisible.
- Skills and competence in homecare services do not receive formal recognition or compensation.

- Judgements made about the degree of complexity and difficulty associated with the use of different equipment tends to underestimate the skills required in female occupations.

Our findings demonstrated a strong match between the theories on low pay and conditions and the New Zealand homecare market. They are summarised in Table 2.

\section{Links between pay, conditions and quality}

There is no definitive definition of what constitutes quality homecare. The literature and our study shows clients regard quality as involving commitment, flexibility about what needs to be done, and stable and personal relationships with workers. For Maori, respect and client/whanau input, community focus, and cultural competence have been identified as important for clients.

From the workers' perspective, access to training and supervision, the balance of power and not being treated like a maid, and not being asked to do additional tasks have been identified as important to the quality of their services.

Eustis and Fischer (1991) concluded that, given the absence of direct supervision and the privacy of the setting, the best assurance of good quality homecare may be the development of congenial, trusting and caring relationships. Little contact with peers or supervisors, inadequate information, and little authority or discretion, have also been identified as having a negative impact on quality (Eustis, 1993).

\section{Quality issues that emerged from the research}

Several areas of quality risk were identified in our study. They were:

- Health and safety risks for workers included poor hygiene, violent clients, sexual harassment, racism and back injuries.

- Most workers had very little personal contact with their coordinator.

- Training varied from agency to agency - only half the workers in our sample had received training. Training time was not paid for in most agencies.

- Providers were generally keen to improve quality through improving the skills and conditions of homecare workers. Three were looking at ways to provide some security of hours and including paid travel time for a core of higher skilled workers in order to improve their responsiveness.

- The directly competitive model of funding may lead to more quality risks, compared with the contestable contracting model, due to stress on providers and difficulty in long term planning 


\begin{tabular}{|c|c|}
\hline $\begin{array}{l}\text { Labour market } \\
\text { segregation }\end{array}$ & $\begin{array}{l}\text { - many workers had characteristics of secondary labour force } \\
\text { - the industry is competitive and has low costs of turnover and training } \\
\text { - some barriers to entry }\end{array}$ \\
\hline $\begin{array}{l}\text { The role of } \\
\text { Government as a } \\
\text { funder }\end{array}$ & $\begin{array}{l}\text { - HFA and ACC as the main funders - very little private business for agencies } \\
\text { - four of the six agencies had around } 90 \% \text { of their business with HFA - all } \\
\text { had at least } 50 \% \\
\text { - the majority of agencies reported being price -takers } \\
\text { - ACC set prices; HFA engaged in negotiation but was guided by historical } \\
\text { costs }\end{array}$ \\
\hline $\begin{array}{l}\text { Contracting and } \\
\text { competition }\end{array}$ & $\begin{array}{l}\text { - Appeared to confirm the findings in the literature that competitive } \\
\text { contracting reduces remuneration }\end{array}$ \\
\hline $\begin{array}{l}\text { Occupational } \\
\text { segregation }\end{array}$ & $\begin{array}{l}\text { Very strong - over } 90 \% \text { of the homecare workers in agencies in our study } \\
\text { were female } \\
\text { - Agencies were female-dominated - managers, care coordinators, and } \\
\text { workers }\end{array}$ \\
\hline Caring occupation & $\begin{array}{l}\text { Workers and care managers reported that homecare workers found it } \\
\text { difficult to not provide care that was needed } \\
\text { - Some evidence of workers doing more for job satisfaction reasons }\end{array}$ \\
\hline Valuing of the job & $\begin{array}{l}\text { - care workers tendency to monitor the clients needs was generally } \\
\text { acknowledged by care coordinators and managers in interviews, but in most } \\
\text { cases not formally assessed as part of performance } \\
\text { - valuing of emotional input more apparent in Maori agencies } \\
\text { - some encouragement of workers to keep a distance - mostly ignored by the } \\
\text { workers (e.g. exchange of phone numbers) } \\
\text { - workers spoke of the care component in their jobs - especially in relation to } \\
\text { personal care and taking clients shopping } \\
\text { - HFA and ACC contracts with the providing agencies, and job descriptions, } \\
\text { tended to focus on concrete tasks, } \\
\text { - High level goals in ACC and Health both assume care and monitoring and } \\
\text { not just tasks } \\
\text { - Assessment processes mostly focus on the physical tasks clients cannot } \\
\text { carry out } \\
\text { - Agencies were keen to recruit former nurses and enrolled nurses - none } \\
\text { were paid as nurses } \\
\text { - Perception that more skilled workers got more complex clients } \\
\text { - Many workers under-described or undervalued their work often saying it is } \\
\text { just common sense or something that all women know how to do } \\
\text { - Workers frequently talked of putting themselves in the clients shoes and of } \\
\text { treating them as they would like to be treated themselves. } \\
\text { - Workers considered they were underpaid for the work they perform } \\
\text { especially for personal care and most considered the unreliability of the } \\
\text { hours and the unpaid time was unacceptable } \\
\text { - The way in which the service is delivered is important to clients. Essential } \\
\text { ingredients noted by clients were respect, thoughtfulness, kindness, } \\
\text { friendliness and honesty. For Maori clients a strong sense of the worker as } \\
\text { whanau is important. }\end{array}$ \\
\hline
\end{tabular}

On the other hand:

- Agencies with contracts that enabled them to "juggle" hours considered this assisted the quality of care. Benefits mentioned included encouraging innovation and efficient use of resources.
- Job turnover varied widely. Recruitment was not generally a problem. Some difficulties however were experienced with personal care workers and with rural work. 


\section{Summarising issues for Maori}

Ten of the 28 workers interviewed were Maori, seven worked for Maori agencies. There was no discernible differences in pay rates between Maori and non-Maori. Workers in Maori agencies, however, appeared to experience a more relaxed employment environment which they saw as supporting emotional and spiritual care. On the other hand, Maori workers faced particular obligations working for Maori clients which are not generally present when working for non-Maori clients.

Maori workers and clients raised concerns about homecare provision more often than non-Maori. A common view held by Maori workers and clients was that the assessment process was inappropriate for Maori. Maori generally prefer whanau care - most of the general agencies did not employ relatives to care for clients. In our study, all but one of the Maori interviewed said they would prefer a service run by Maori for Maori.

\section{Future research}

One of the key findings of the study is the gap in the nominal and effective wage rates of homecare workers. It is not known how many other occupations contain requirements that oblige workers to contribute their own time or resources free of charge as part of their normal job. It is also not know whether such obligations are spread evenly across occupation groups, and what the impact of any uneven spread has on the ratio of effective pay rates between different ethnic groups, and men and women.

\section{References}

Aronson, J. and Neysmith, S.M. (1996) You're not just in there to do the work: Depersonalising policies and the exploitation of home care workers' labour, Gender and Society, 10(1):59-77.

Baylis, C. (1997) Gendering Judgements: Cashman v Central Regional Health Authority, New Zealand Law Review: 116-139

Brodkin Sacks, K. (1990) Does it pay to care? in E. Abel and M. Nelson (eds), Circles of Care: Work and Identity in Women's Lives, State University of New York Press, Albany, NY.

Burbridge, L. (1993) The labor market for home care workers: Demand, supply and institutional barriers, The Gerontologist, 33(1):41-46.

Equal Opportunities Commission for Northern Ireland, (1996) Report on the Formal Investigation into Competitive Tendering in Health and Education Services in Northern Ireland, The Commission, Belfast.

Eustis, N. and Fischer, L. (1991) Relationships between home care clients and their workers: implications for quality of care, The Gerontologist, 31(4):447456.

Eustis, N., Kane R. and Fischer L. (1993) Home care quality and the home care worker: beyond quality assurance as usual. The Gerontologist, 33(1):64-73.

Fisher, B. (1990) Alice in the human services: A feminist analysis of women in the caring professions, in E. Able and M. Nelson (eds), Circles of Care: Work and Identity in Women's Lives, State University of New York Press, Albany, NY, pp.108131.

Freytag, K. (1997) Contracting Out: An Anti-discrimination Perspective, paper adapted from the seminar: Contracting out: Pitfalls, Problems and Possibilities - A Look at Domestic and International Patterns of Contracting Out and the Impacts on Working Women, Wellington, 28 July 1997.

MacAdam, M. (1993) Home care reimbursement and effects on personnel, The Gerontologist, 33(1):5563.

Mulgan, R. (1997) Contracting out and accountability, Australian Journal of Public Administration, 56(4):106-116.

Munford, R. (1990) The hidden costs of caring: the experiences of women caregivers, Women's Studies Journal, Nov. 1990:28-45.

Neysmith, S.M. and Aronson, J. (1996) Home care workers discuss their work: The skills required to use your common sense, Joumal of Aging Studies, 10(1): $1-14$

Poole, M. and Issacs, D. (1997) Caring: A gendered concept, Women's Studies International Forum, 20(4):529-536.

Ratima M.M., Durie, M.H., Allan, G.R., Morrison, P.S., Gillies, A. and Waldon, J.A. (1995) He Anga Whakamana: A Framework for the Delivery of Disability Support Services for Maori, Core Services Committee, Wellington.

Remick, H. (ed.) (1984) Comparable Worth and Wage Discrimination: Technical Possibilities and Political Realities, Philadelphia: Temple University Press,

Tanner, C., Benner, P., Chesla, C. and Gordon, D. (1996) The phenomenology of knowing the patient, in $S$. Gordon et al (eds), Caregiving; Readings in Knowledge, Practice, Ethics and Politics, University of Pennsylvania Press, Pittsburgh.

Tarlow, B. (1996) Caring; a negotiated process that varies, in S. Gordon et al (eds), Caregiving; Readings in Knowledge, Practice, Ethics and Politics, University of Pennsylvania Press, Pittsburgh.

\section{Author}

Máire Dwyer is a Consultant,

3/262 Oriental Parade,

Oriental Bay, Wellington.

E-mail: maire@wgtn.planet.org.nz 